\title{
Childhood Renal Cell Carcinoma
}

National Cancer Institute

\section{Source}

National Cancer Institute. Childhood Renal Cell Carcinoma. NCI Thesaurus. Code C6568.

A renal cell carcinoma that occurs during childhood. 